\title{
Clientelism and vote buying in low-cost housing provision: A case study of the Greater Giyani Local Municipality, Limpopo province of South Africa
}

\begin{tabular}{|c|c|}
\hline \multicolumn{2}{|c|}{$\begin{array}{l}\text { Authors: } \\
\text { Ntwanano E. Mathebula }{ }^{1} \\
\text { Mokoko P. Sebola }{ }^{1} \text { (] }\end{array}$} \\
\hline \multicolumn{2}{|c|}{$\begin{array}{l}\text { Affiliations: } \\
{ }^{1} \text { Department of Public } \\
\text { Administration, Faculty of } \\
\text { Management and Law, } \\
\text { University of Limpopo, } \\
\text { Polokwane, South Africa }\end{array}$} \\
\hline \multicolumn{2}{|c|}{$\begin{array}{l}\text { Corresponding author: } \\
\text { Ntwanano Mathebula, } \\
\text { hongonyi@gmail.com }\end{array}$} \\
\hline \multicolumn{2}{|c|}{$\begin{array}{l}\text { Dates: } \\
\text { Received: } 19 \text { Nov. } 2019 \\
\text { Accepted: } 19 \text { Aug. } 2020 \\
\text { Published: } 07 \text { Dec. } 2020\end{array}$} \\
\hline \multicolumn{2}{|c|}{$\begin{array}{l}\text { How to cite this article: } \\
\text { Mathebula, N.E. \& } \\
\text { Sebola, M.P., 2020, } \\
\text { 'Clientelism and vote buying } \\
\text { in low-cost housing provision: } \\
\text { A case study of the Greater } \\
\text { Giyani Local Municipality, } \\
\text { Limpopo province of South } \\
\text { Africa', Africa's Public Service } \\
\text { Delivery and Performance } \\
\text { Review 8(1), a364. https:// } \\
\text { doi.org/10.4102/apsdpr. } \\
\text { v8i1.364 }\end{array}$} \\
\hline \multicolumn{2}{|c|}{$\begin{array}{l}\text { Copyright: } \\
\text { ( 2020. The Authors. } \\
\text { Licensee: AOSIS. This wc } \\
\text { is licensed under the } \\
\text { Creative Commons } \\
\text { Attribution License. }\end{array}$} \\
\hline \multicolumn{2}{|l|}{ Read online: } \\
\hline 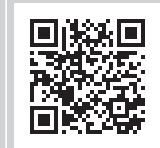 & $\begin{array}{l}\text { Scan this QR } \\
\text { code with your } \\
\text { smart phone or } \\
\text { mobile device } \\
\text { to read online. }\end{array}$ \\
\hline
\end{tabular}

Background: This article seeks to examine ethical dilemmas and clientelism in the allocation of low-cost houses using 10 selected villages under the jurisdiction of the Greater Giyani Local Municipality area as units of analysis. The hypothesis of the initial research was that political parties in control of government machinery employ low-cost houses as electioneering instruments.

Aim: The aim of the article therefore is to investigate the extent to which clientelism and clientelistic strategies such as vote buying are pertinent to the housing provision.

Setting: The research was guided by this question: what are the features of clientelism and their extent to the provision of low-cost houses at the Greater Giyani Local Municipality area?

Methods: Mixed methods approach was used to solicit primary data in relation to clientelism and vote buying in the provision of low-cost houses.

Results: The findings as presented in the article suggest that clientelism and vote buying are used in the allocation of low-cost houses but not to a larger extent as assumed. The findings therefore are not presenting a crystal clear picture regarding the manifestation of clientelism and vote buying specifically in relation to low-cost housing allocation.

Conclusion: The article makes a significant contribution to the discourse on housing allocation in general and low-cost houses in particular, especially given the fact that it is located within clientelism and the strategies used in electioneering. The article further contributes to the discipline of Public Administration, Public Policy and to some extent politics. Studies in these areas fail to give attention to issues of public policy, ethics and clientelism. Municipalities and other housing provision authorities stand to benefit from the findings and the recommendations thereof. The article has the potential to shape legislative frameworks and procedures through which low-cost houses are allocated.

Keywords: clientelism; vote buying; low-cost houses; electioneering; ethical dilemmas.

\section{Introduction}

Section 26(1) of the Constitution of the Republic of South Africa (Hereafter referred to as the 1996 Constitution) states that 'everyone has the right to have access to adequate housing'. Low-cost houses which became commonly known as 'Reconstruction and Development Programme (RDP) houses' befitted government's approach in responding and respecting the constitutional right to adequate housing for all 'deserving' South Africans. In terms of the Breaking New Ground Policy of 2004 a low-cost house is one typology of social housing. In terms of such policy, social housing takes various forms such as flats, apartments, cooperative group transitional housing and shared hostels in order to include all income groups. In this article, a low-cost house is defined as housing for people whose combined monthly household incomes are below R3500 per month. According to Tam (2011:156), a low-cost house can be understood as any housing unit which is considered suitable for low- and moderate-income earners who are unable to access the housing market. The article argues that despite this constitutional ambition the ruling African National Congress (ANC) utilises provision of low-cost houses for clientelistic and vote-buying propensities. The argument is premised on the view that there has been a neglect of legislative prescripts and frameworks underpinning the allocation of low-cost houses with focus shifting to political-scores settling and electioneering.

The year 2015, was declared the year of the Freedom Charter by the South African government (Suttner 2015). Amongst other declarations of the Freedom Charter (1955) is that; 'there shall be 
houses, security and comfort for all'. More than 60 years into these ambitions and aspirations, millions of South Africans continue to live in shacks, thatched houses, subjected to squalid conditions and abject poverty (Socio-Economic Rights Institute of South Africa 2018). The advent of democracy in 1994, presented a window of opportunities and prospects for a better South Africa (The World Bank 2015). This was a stage whereby hopeless South Africans saw an opening through the provisions enshrined within the 1996 Constitution. It was also an era in which government promulgated various pieces of legislation and policies to address socio-economic challenges including housing. Amongst others, the 1996 Constitution through the Bill of Rights (Chapter 2) guarantees rights to housing, social security, property, equality and dignity. Despite all this, the provision of low-cost housing in South Africa by the three spheres (National, Provincial and Local) of government is confronted by major challenges (Nattrass 2014). Despite good policy intentions of boosting asset ownership, access to opportunities and elimination of asset capital poverty (Charlton \& Kihato 2006), the housing programme is concocted and manifested with clientelism in almost all aspects from the application processes, actual delivery and handing over of title deeds (Rubin 2011). Clientelism and vote buying are also utilised as mechanisms for political parties (Wantchekin 2003) whereby government houses are allocated by politicians to undeserving beneficiaries in exchange for votes. Underserving beneficiaries whose combined monthly household income exceeds R3500 as per the legislative frameworks governing the allocation of lowcost houses in South Africa. According to Hopkin (2006), clientelism is a form of a transaction whereby the patron (politicians in power) provide clients (the public) with access to the basic means of subsistence and the clients reciprocating with a combination of economic goods and services and social acts of deference and loyalty. In the context of this article and the study conducted, clientelism is the exchange of votes and low-cost houses between political deployees and the general citizenry. Politicians use their discretionary power to create a 'lock-in effect in resource allocation', (Wantchekin 2003) in this case low-cost houses.

The general question in this study is: what are the ethical dilemmas and clientelistic tendencies in the allocation of lowcost houses in the Greater Giyani Local Municipality? To guide this question, the following specific research questions were used:

- What are the features of clientelism in relation to the allocation of low-cost housing in selected communities within the Greater Giyani Local Municipality?

- What is the extent of low-cost housing allocation with specific reference to selected communities within the Greater Giyani Local Municipality?

- What is the extent to which housing policies are conformed to in the allocation of low-cost housing within the Greater Giyani Local Municipality with specific reference to selected communities?

\section{Conceptualising clientelism and vote buying: A theoretical overview}

The buying of votes through the use of public goods such as food parcels, money or even social houses such as low-cost houses raises very serious issues of morals and ethics (Nattrass 2014). This is because public goods are offered to political party's loyal and affiliated members whilst the rightful and qualifying beneficiaries are excluded. Ruling political parties are responsible or at least likely to engage in vote buying and other clientelistic strategies or the so-called 'machine-politics' as they are entrusted with the control of public resources.

\section{Clientelism}

Historian, Richard Graham states that clientelism is premised upon the principle of 'take there, give here' which enables both clients and patrons to mutually benefit politically, socially and administratively (Roniger 2004). Clientelism is the direct exchange of a citizen's vote in return for direct payments or access to employment, goods and services (Guardado \& Wantchekon 2017). The term clientelism creates challenges and confusion in defining because of a wide and diverse range of political exchanges, which can be subjected to the meaning and definition of the concept. In the political space, clientelism specifically relates to the use of public resources in exchange for votes. The privileges conferred to a client may include amongst others: employment opportunities, food parcels, clothing and housing, which have been funded through the taxpayer's money. This according to Roniger (2004), implies that the patron benefits through selective processes to public resources whilst others are excluded. According to Hopkin (2006), clientelism is a form of personal, dyadic exchange characterised by obligation and unequal power balance between the patron and client whereby patrons provide clients with access to economic goods and services and social acts of deference loyalty. Clientelism can also be understood as a political exchange whereby a patron gives patronage in exchange for the vote or support of a client (Robinson \& Verdier 2013). Directly borrowing from the words of Scott (1972), clientelism is:

[A] special case of two persons in a tie involving a largely instrumental friendship in which an individual of higher socioeconomic status uses his own influence and resources to provide protection or benefits, or both, for a person of lower status who, for his part, reciprocates by offering general support and assistance, including personal services, to the patron. (p. 92)

From Scott's understanding of clientelism, it can be seen that clientelism is a relationship between two individuals with one (patron) uses his social class and status to influence a poor person (client) to vote for him or his party in exchange of material benefits.

In the context of this article, clientelism is viewed as the offering of government low-cost houses particularly to poor people in exchange for votes in either local government or 
national elections. The argument is that clients without RDP houses are prone to change or be influenced of their political choices on the basis of having been offered a house, which he did not own before. It is no doubt that with the high prevalence and the unfairness in the distribution and allocation of low-cost housing that votes are being bought.

\section{Vote buying}

Vote buying is a transaction between candidates and electorates to whom goods are distributed to the latter in exchange of electoral support for the former. According to Gonzalez-Ocantos et al. (2015), vote buying is one of the viable clientelistic approaches that has the potential to reduce voter turnout. It can therefore be deduced that there is a strong relationship between vote buying and turnout buying as clientelistic strategies adopted by political parties seeking to win the machinery of government. It can further be drawn that political parties may also utilise the mixture of clientelistic strategies rather than depending on a single one. Vote buying is a strategy that may be seen as unambiguously harmful for democracy as it undermines free and fair elections (Schaffer \& Schedler 2007) by allowing those parties controlling public resources to manipulate the poor. Nichter (2008) argued that implications of this clientelistic strategy are ambiguous as it increases political participation equality by inducing the poor to vote.

This article acknowledges that other studies (see Aduwo 2011; Ajayi 2012; Mathebula 2020; Ngwadla 2005; Ngxubaza 2010; Ntema 2011; Sabela 2014; Sadeque 2013) have been carried out on the provision and allocation of low-cost houses. However, this article bears its uniqueness as it critically tackles the inherent ethical dilemmas and clientelism related to the allocation of low-cost housing.

\section{Research methods}

In an attempt to understand the clientelism and vote buying and its extent in the allocation of low-cost housing in the Greater Giyani Municipality area, this article adopted a mixed-methods approach whereby a questionnaire was distributed to solicit primary data using predetermined questions in the form of Likert Rate Scales. The questionnaire comprised five scales: strongly agree, agree, neutral, strongly disagree and disagree. Supplementary interviews were also conducted as a form of a qualitative approach of data collection so that some views can be used to complement the quantitative elements. Residents from Thomo, Muyexe, Homu, Ndhambhi, Ngove, Mphagani, Nhlaniki, Mapuve, Nkurhi and Xikukwani villages under the jurisdiction of the Greater Giyani Local Municipality were randomly selected so that a generalisation can be drawn in relation to the impact of clientelism and vote buying in low-cost housing provision. A purposive sampling technique was adopted whereby 300 participants were selected on the basis of their knowledge and expertise on ethical dilemmas in relation to the allocation of low-cost houses. Purposive or judgemental sampling technique involve selecting certain units or case 'based on specific purpose rather than randomly' (Teddlie \& Yu 2007:80). Amongst the 300 participants, 150 were respondents who benefited from low-cost houses whilst the other half were those 'deemed' to be qualifying beneficiaries but have not received houses despite the fact that they have applied. Quantitative data were subjected to a Statistical Package of Social Sciences (SPSS) whilst data collected from interviews were categorised into specific thematic areas and analysed as such.

\section{Presentation of data, analysis and results}

Before data were collected, letters of permission to conduct the study were addressed to traditional leaders and traditional councils, respectively. Community residents voluntarily participated in the study. All ethical considerations governing research at the University were thoroughly explained. As a result of high levels of illiteracy in the selected village areas, some respondents were assisted in their home languages in responding to the set questions and scales. Supplementary interviews were conducted with community members with a view of following up to questions as presented in the questionnaire. The idea was that residents might want to say more than what has already been presented in the questionnaire. The data were therefore presented in different themes.

\section{Political affiliation in the allocation of low-cost houses}

The rationale for probing political affiliation in the allocation of low-cost houses was to solicit views on whether those with RDP houses got them by virtue of being affiliated to the ruling party. The Greater Giyani Municipality as the unit of analysis is currently governed by the ANC. Summary of the results are presented in Figure 1 with itsdescription.

The findings of the given figure indicate that majority (34\%) of the respondents strongly disagree that political affiliation is used in the allocation of low-cost houses. That is followed by $25 \%$ of the respondents who disagree that political affiliation is used in the allocation of low-cost houses. On the contrary, $20 \%$ of the respondents agree, $16 \%$ strongly agree whilst only $5 \%$ of the respondents are neutral. Collectively, $59 \%$ of the respondents negate the fact that political party



FIGURE 1: Allocating RDP houses using political affiliation. 
affiliation has anything to do in the allocation of low-cost houses. However, $36 \%(20 \%+16 \%)$ of the respondents who are of the view that political affiliation in the allocation of low-cost houses cannot be underestimated. On the basis of this, it can be deduced that the case of the prevalence of political affiliation in low-cost housing is not very clear, this is given the fact that $5 \%$ of the respondents are undecided on the question. It can therefore be concluded on the basis of findings that there is no or little relationship between political affiliation and the allocation of low-cost houses. These findings are contrary to the findings of the study conducted by Bahre (2011), who holds that, whilst corruption is rife, political affiliation is used in the allocation of public resources such as social houses. The article therefore argues that respondents who don't have houses have agreed to an existing relationship between housing allocation and political party affiliation. Furthermore, opposition party members are also likely to hold a view of such an existing relationship.

\section{Political connection and housing allocation}

Unlike affiliation which refers to membership of a party, political connection refers to preferential treatment for those in close proximity to incumbents controlling public resources through the enactment of favourable policies and conducive environment for the purposes of illicit access to public resources (Akouwerabou 2016). In the context of this article, political connection is used to refer to preferential treatment of potential voters by politicians in power in the allocation of low-cost houses. This manifests whether or not the potential voters are loyal and affiliated party members. This study therefore asked the respondents whether low-cost houses were allocated based on their close connectedness with the politicians? Figure 2 presents the findings whilst its analysis is provided later.

The findings in the given figure indicate that majority $(28 \%)$ of the respondents strongly disagree that political connections are used in the allocation of low-cost houses. Respondents who disagree and strongly agree on the relationship between low-cost houses allocation and political connection each scored 23\%. Furthermore, $18 \%$ of the respondents agree, whilst $8 \%$ is undecided on whether low-cost houses are allocated on the basis of political connection. This finding fails to paint a clearer picture as collectively, $51 \%$ of the respondents disagree, whereas $41 \%$ agree. It must however be conceded that respondents

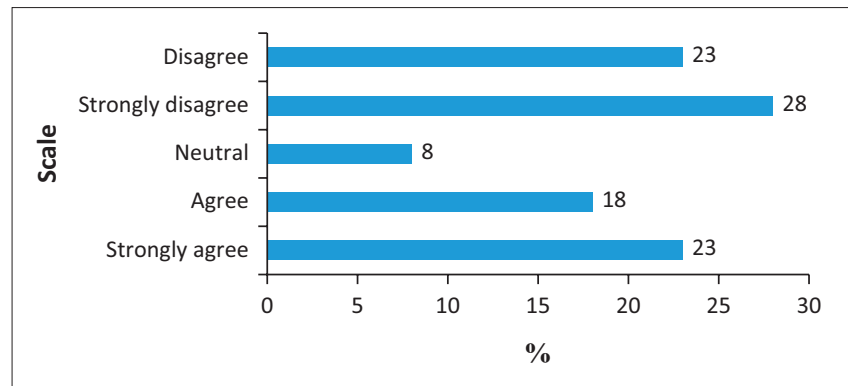

FIGURE 2: Political connections used in the allocation of low-cost houses. might have failed to comprehend the meaning of political connection particularly in the context of low-cost housing. Having to rely on the statistics on this and Figure 1 it can however be concluded that issues of political connections in the allocation of low-cost housing in the area of study are prevalent.

\section{Joining a political party promising a house}

The rationale for probing this theme was to solicit the views of respondents on the potential of low-cost houses in persuading voters in changing their voting patterns and joining another political party. Put simply, the question arising would be whether political parties promising respondents low-cost houses would persuade them through promises to join another political party?

The findings of the given figure indicate that there is a strong relationship between low-cost housing and respondents being promised a house to join a political party. A total of $36 \%$ of the respondents strongly agree that they would join a political party promising them a low-cost house, whilst $28 \%$ of the respondents agree. A total of $16 \%$ of the respondents disagree that they would join a political party promising them a low-cost house, whilst $14 \%$ strongly disagree. A mere $6 \%$ of the respondents are undecided on their choices to join a political party on the basis of a mere promise. The given findings confirm the literature in the sense that non-voters and non-affiliated members through the clientelistic approach of double persuasion are likely to be induced into voting processes as they initially don't believe in any ideology of any political party. Double persuasion confers benefits to potential electorates for the purposes of inducing their voting choices and participation in the processes (Gans-Morse, Mazzuca \& Nichter 2014). Even though majority of electorates in matured democracies elect political parties based on ideologies, clientelistic parties use double persuasion as a clientelistic strategy. Chubb (1982) is of the view that double persuasion is a strategy whereby machineries distribute benefits to nonvoters who normally had varying political ideologies from those of machineries.

It is somehow mindboggling to think that some respondents are unlikely to join a political party promising them a house.

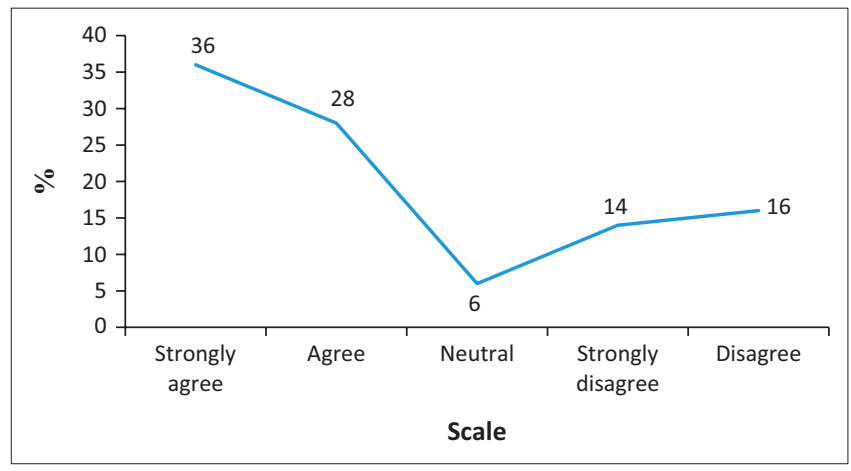

FIGURE 3: Promises can lead to joining a party. 
In a supplementary interview, one of the respondents indicated that they would never join any political party, even if they were promised a job or money. According to the respondent politicians are liars and rely on promises to gain votes, then disappear. Another respondent stated that promises are made and remain as such, as they are still waiting on water and tar roads.

These and other sentiments are a clear indication that some people on the ground no longer listen to the promises of politicians and would therefore not be induced into joining political parties and voting for them.

\section{Voting a political party promising a house}

The data and results above were meant to test the relationship between promises for a housing and voting for a political party concerned. It must therefore be borne in mind that, even if the respondents would have either agreed to join a political party on the basis of having been promised a lowcost house that would not necessarily mean that they would vote for such a political party in elections. The question to the respondents was therefore, whether they would vote for a political party that promises them a low-cost house?

The results in the given figure indicate that $34 \%$ of the respondents strongly agree that they would vote for a political party promising them low-cost houses. On the contrary, $21 \%$ of the respondents disagree whilst $11 \%$ strongly disagree. Furthermore, 19\% of the respondents agree that they would vote a political party promising them a low-cost house whilst $15 \%$ are undecided or neutral. From these findings it can be seen that 53\% (34\% + 19\%) agrees to the fact that promises for low-cost housing have the potential to influence them to vote for a political party promising houses. It can therefore be concluded on the basis of these results that political parties promising voters a house have the potential of increasing their membership and poll results. These findings also serve to confirm the perused

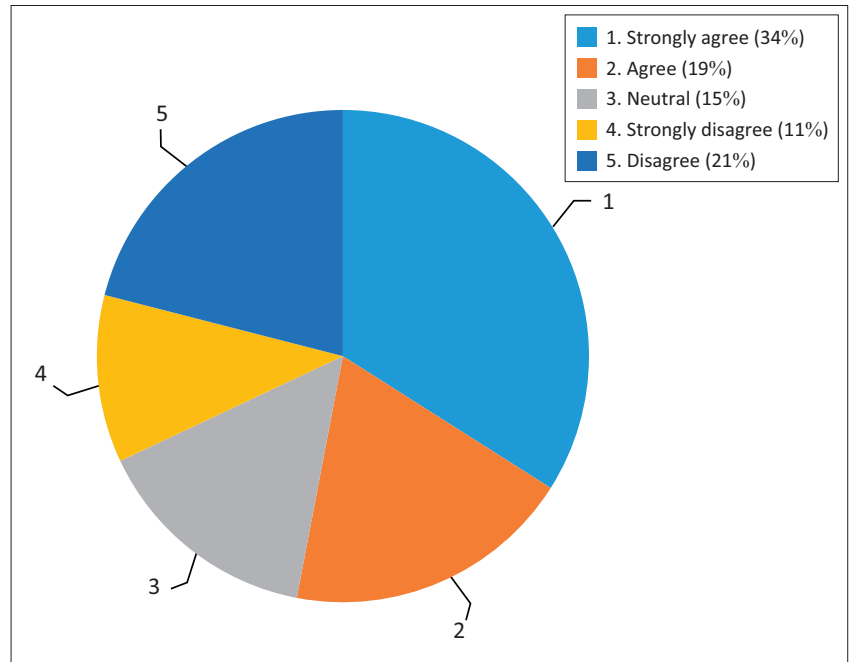

FIGURE 4: Promises can lead to voting for a party. literature on the potential of public goods on voters changing their political choices and voting behaviour (Van de Walle 2003). Furthermore, in a survey conducted by Patel et al. (2014), in three selected poor settlements in South Africa, $65 \%$ of the respondents held that they would vote for a party that promises to look after their households by any means whilst 59\% would vote for a party that provided them with social grants.

\section{Changing a political party for a promised house}

The last two figures of this section of the data analysis were aimed at establishing the relationship between the allocation of low-cost houses with the influence to join and vote for a political party promising them low-cost houses. The data in the given figure were probed for the purposes of understanding the influence and the relationship between a promise for a low-cost house and the respondents' willingness to switch between political parties. Respondents were asked to reply to a statement on whether they would change their current political party to one that promises them a low-cost house.

The findings of the given figure indicate that a majority of $39 \%$ of the respondents agree that they would change their political party if another party promised them a low-cost house, whilst $14 \%$ strongly agree. Furthermore, 25\% of the respondents disagree that they would change their current political party to another that promises them a low-cost house whilst $18 \%$ strongly disagree. Only $4 \%$ of the respondents were neutral and undecided on whether they would change their current political parties to a party promising them a low-cost house. On an average, 53\% of the respondents agree that they would change their current political parties to another party promising them low-cost houses. On the contrary $43 \%(14 \%+39 \%)$ of the respondents, which is a substantial number, are of the view that they will not change to a political party that promises them a lowcost house. It can therefore be concluded that although majority of the respondents are of the view that there is a strong relationship between the allocation of low-cost houses and changing a political party.

Findings of the three given figures are confirmed by the results of a survey conducted by Patel et al. (2014) in South Africa as indicated here:

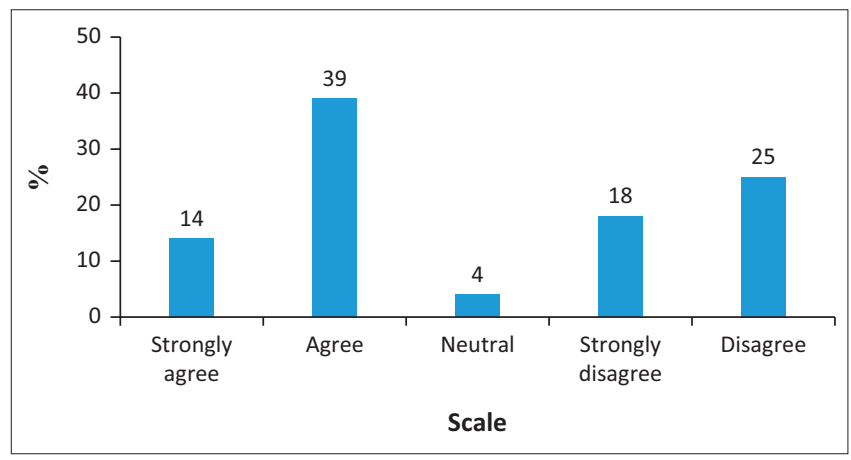

FIGURE 5: Changing a political party. 


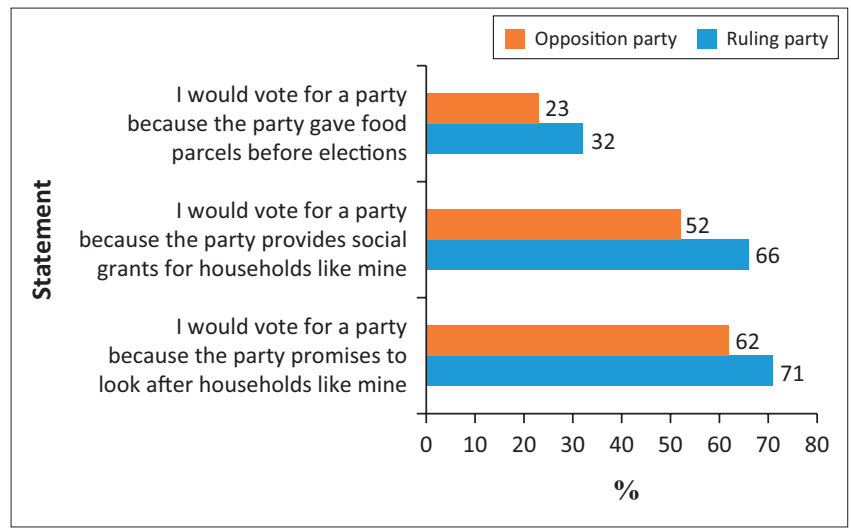

Source: Patel, L., Sadie, Y., Graham, V., Delany, A. \& Baldry, K., 2014, Voting behaviour and the influence of social protection. A study of voting behaviour in three poor areas in South Africa, Centre for Social Development in Africa, University of Johannesburg, Johannesburg.

FIGURE 6: Agreements with statements relating to voting for a party based on potential benefits, by party preference.

\section{People benefited from low-cost houses for having affiliated to the African National Congress}

The rationale for specifically probing affiliation to the ANC was solely based on the fact that the Greater Giyani Local Municipality is an ANC-governed municipality. Furthermore, majority of South African municipalities and the national government are ANC governed. In terms of the perused literature, governing political parties use public resources such as low-cost houses in exchange for votes during elections. Hence in this section, the reason for the probe was to solicit views on whether the governing ANC is clientelistic in allocating low-cost houses.

Findings of the given figure indicate that $31 \%$ of the respondents strongly disagree that those beneficiaries with low-cost houses are affiliated to the ANC whilst $21 \%$ disagree. On the contrary, $20 \%$ of the respondents strongly agree that those with low-cost houses are affiliated members of the ruling ANC whilst $17 \%$ agree. Lastly, only $11 \%$ of the respondents were undecided. On the aggregate $52 \%$ of the respondents dispute the fact that political affiliation particularly to the ruling political party is used in the allocation of low-cost houses. On the one hand, only $11 \%$ of the respondents were undecided. On the aggregate $52 \%$ of the respondents dispute the fact that political affiliation particularly to the ruling political party is used in the allocation of low-cost houses. It can be argued that respondents who are of the view that political affiliation is used in the allocation of low-cost houses could be those deserving beneficiaries who have not received houses from government. The given findings however do not really give a clearer picture of the reality on the ground, especially when $11 \%$ of the respondents are hesitant to give a straightforward response. However, the findings are contrary to the literature of parties such as the Peronist in Argentine (Nichter 2008) which used its control of state machinery to allocate public goods and services in exchange for votes.

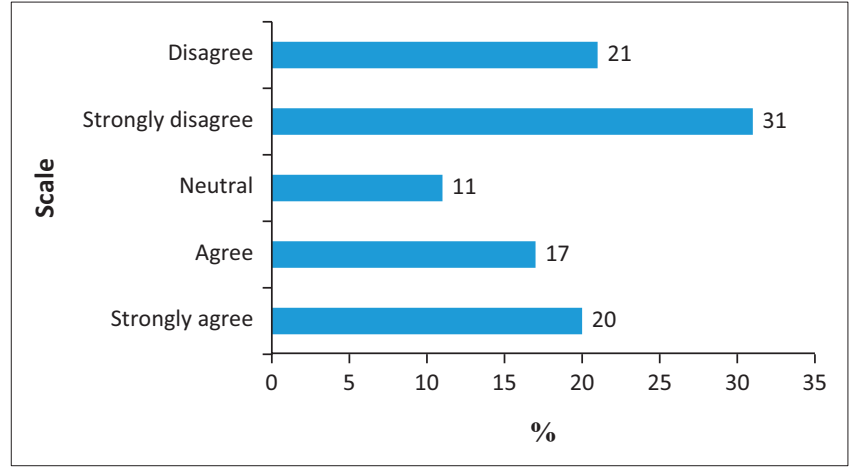

FIGURE 7: Political affiliation used in housing allocation.

\section{Conclusion and recommendations}

The aim of this article was to investigate clientelism and vote buying in the allocation of low-cost houses in the Greater Giyani Municipality, Limpopo province using 10 selected villages within the jurisdiction of the Municipality. The conclusion therefore is that there seem to exist certain elements of clientelism and vote buying in relation to the allocation of low-cost houses. Based on the analysis of data, the researcher cannot establish a significant correlation between clientelism and vote buying in the allocation of low-cost houses. This may be attributed to sample of participants that were selected for the study. The sample of participants made up of those with houses and those without houses, this may have influenced their responses. It would seem that there is still a strong belief amongst residents that low-cost housing allocation was influenced by relations and influence of political parties. Against this background the article proposes:

- For a low-cost housing system that is free from political interference. It was found in the study that political parties rely on low-cost houses as electioneering machinery (i.e. clientelism). Therefore, politics must be removed from the execution of the housing function so that it remains a function of government executive institutions.

- For the amendment of the Electoral Act (73 of 1998). The aim was to guard against unfair electoral practices such as clientelism and vote-buying phenomena. This is so important as political parties do not have an equal playing field during electioneering because of the lack of resources, which are used to campaign for votes. In other words, there is unfair competition in electoral processes.

- For civic and democratic education and civil rights. This is so important particularly in rural areas such as those that formed part of this study. This is so as majority of the citizenry lack understanding with regard to their rights to receiving services such as low-cost houses. Majority of the respondents in this study were of the view that the governing ANC is responsible for ensuring that they receive houses whilst this is a fundamental basic right as enshrined in the 1996 Constitution. 


\section{Acknowledgements Competing interests}

The authors have declared that no competing interests exist.

\section{Authors' contributions}

Both authors contributed equally to this work.

\section{Ethical consideration}

Ethical clearance was obtained from the Turfloop Research Ethics Committee (TREC), University of Limpopo on 06 December 2018, reference number: TREC/225/2018: PG.

\section{Funding information}

This research received no specific grant from any funding agency in the public.

\section{Data availability statement}

Data sharing is not applicable to this article as no new data were created or analysed in this study.

\section{Disclaimer}

The views and opinions expressed in this article are those of the authors and do not necessarily reflect the official policy or position of any affiliated agency of the authors.

\section{References}

Aduwo, B.E., 2011, 'Housing transformation and its impact on neighbourhoods in selected low-income public housing estates in Lagos, Nigeria', PhD thesis, Dept. of Architecture, Covenant University.

Ajayi, J.R., 2012, 'Strategies for sustainable housing co-operatives in South Africa', PhD thesis, Dept. of Construction Management, Faculty of Engineering, the Built Environment and Information Technology, Nelson Mandela Metropolitan University.

Akouwerabou, B.D., 2016, 'Entrepreneurs establishing political connection: Do they finance political parties or politicians?', SAGE Open 6(3), July-September, 1-12. https://doi.org/10.1177/2158244016665889

Bahre, E., 2001, 'Housing for the urban poor in Cape Town: A post-apartheid dream or nightmare?', GBER 1(1), 33-44.

Charlton, S. \& Kihato, C., 2006, 'Reaching the poor? An analysis of the influences on the evolution of South Africa's Housing Programme', in U. Pillay, R. Tomlinson \& J. du Toit (eds.), Democracy and delivery: Urban policy in South Africa, pp. 252-282, HSRC Press, Cape Town.

Chubb, J., 1982, Patronage, power and poverty in Southern Italy: A tale of two cities, Cambridge University Press, Cambridge.

Gans-Morse, J., Mazzuca, S. \& Nichter, S., 2014, 'Varieties of clientelism: Machine politics during elections', American Journal of Political Science 58(2), 415-432. https://doi.org/10.1111/ajps.12058

Gonzalez-Ocantos, E., De Jonge, C.K. \& Nickerson, D.W., 2015, 'Legitimacy buying: The dynamics of clientelism in the face of legitimacy challenges', Comparative Political Studies, 48(9), 1127-1158. https://doi.org/10.1177\%2F0010414015574882

Guardado, J. \& Wantchekon, L., 2017, Do electoral handouts affect voting behaviour? Afro Barometer, Working Paper No. 171, viewed n.d., from http://afrobarometer. org/sites/default/files/publications/Working\%20papers/afropaperno171_ electoral_handouts_and_voting_behavior.pdf
Hopkin, J., 2006, 'Conceptualizing political clientelism: Political exchange and democratic theory', Paper prepared for APSA annual meeting Philadelphia, PA, 31 August-3 September 2006, Panel 46-18 'Concept Analysis: Unpacking Clientelism, Governance and Neoliberalism', viewed 12 October 2016, from http://citeseerx.ist. psu.edu/viewdoc/download?doi=10.1.1.503.5516\&rep=rep1\&type =pdf.

Mathebula, N.E., 2020, 'Ethical Dilemmas and Clientelism in the Allocation of LowCost Housing in the greater Giyani local municipality, Limpopo province, PhD thesis, Dept. of Administration, University of Limpopo.

Mouton, J., 2014, Understanding Social Research, Van Schaik Publishers, Pretoria.

Nattrass, N., 2014, 'South Africa: Post-apartheid democracy and growth', in Voices from the South, Centre for Development and Enterprises, viewed 09 October 2016 from http://www.cde.org.za/wp-content/uploads/2014/04/democracy-works--south-africa-conference-paper---post-apartheid-democracy-and-growth---bynicoli-nattrass-pdf-.pdf.

Ngwadla, M.M., 2005, 'An evaluation of the housing policy in Kwazulu-Natal: A case study of the Durban metropolitan area', unpublished PhD thesis, Dept. of Administration, University of KwaZulu-Natal.

Nichter, S., 2008, Vote buying or turnout buying? Machine politics and the secret ballot', American Political Science Review 102(1), 19-31. https://doi.org/10.1017/ S0003055408080106

Ntema, L.J., 2011, 'Self-help housing in South Africa: Paradigms, policy and practice', PhD thesis, Faculty of The Economic and Management Sciences (Centre for Development Support), University of the Free State.

Patel, L., Sadie, Y., Graham, V., Delany, A. \& Baldry, K., 2014, Voting behaviour and the influence of social protection. A study of voting behaviour in three poor areas in South Africa, Centre for Social Development in Africa, University of Johannesburg, Johannesburg.

Republic of South Africa, 1996, Constitution of the Republic of South Africa, Government Printer, Pretoria.

Republic of South Africa, 2004, Breaking new ground: A comprehensive plan for the development of sustainable human settlements, Government Printer, Pretoria.

Robinson, J.A. \& Verdier, T., 2013, 'The political economy of clientelism', Scandinavian Journal of Economics 115(2), 260-291. https://doi.org/10.1111/sjoe.12010

Roniger, L., 2004, 'Review: Political clientelism, democracy and market economy', Comparative Politics 36(3), 353-375. https://doi.org/10.2307/4150135

Rubin, M., 2011, 'Perceptions of corruption in the South African housing allocation and delivery programme: What it may mean for accessing the state', Journal of Asian and African Studies 46(5), 479-490. https://doi.org/10.1177/0021909611403706

Sabela, P.T., 2014, 'Towards an alternative development approach to low cost housing delivery in KwaZulu-Natal province', PhD thesis, Dept. of Anthropology and Development Studies, University of Zululand.

Schaffer, F.C., 2007, 'Lessons learned', in F.C. Schaffer (ed.), Elections for sale: The causes and consequences of vote buying, pp. 183-200, Lynne Rienner Publishers, Boulder, CO.

Scott, J.C., 1972, 'Patron-client politics and political change in Southeast Asia', The American Political Science Review 66(1), 91-113. https://doi.org/10.2307/1959280

Socio-Economic Rights of South Africa, 2018, Eight years since Marikana, the brutality and the lack of accountability continues, viewed. n.d., from https://www.seri-sa. org/index.php/more-news

Suttner, R., 2015, 'The freedom charter @ 60: Rethinking its democratic qualities', Historia 60(2), 1-23. https://doi.org/10.17159/2309-8392/2015/V60N2A1

Tam, V.M.Y., 2011, 'Cost effectiveness of using low cost housing technologies in construction', Procedia Engineering 14(1), 156-160. https://doi.org/10.1016/j. proeng.2011.07.018

Teddlie, C. \& Yu, F., 2007, 'Mixed methods sampling. A typology with examples', Journal of Mixed Methods Research 1(1), 77-100.

The Congress of the People, 1955, The Freedom Charter, viewed. n.d., from http:// www.historicalpapers.wits.ac.za/inventories/inv_pdfo/AD1137/AD1137-Ea6-1001-jpeg.pdf

The World Bank, 2015, South Africa economic update, Jobs and South Africa's, viewed 30 June 2017, from http://documents.worldbank.org/curated/en/ $479161467998767997 / \mathrm{pdf} / 98880-$ W P-P131437-PUBLIC-8-17-15Box393184B.pdf.

Van de Walle, N., 2003, 'Presidentialism and clientelism in Africa's emerging party systems', Journal of Modern African Studies 41(2), 297-321. https://doi. org/10.1017/S0022278X03004269

Wantchekin, L., 2003, 'Clientelism and vote behaviour: Evidence from field experiment in Benin', World Politics 5(1), 399-422. https://doi.org/10.1353/wp.2003.0018 